\title{
PREVALENCE OF IRON DEFICIENCY ANEMIA IN ANEMIC PATIENTS: A HOSPITAL BASED STUDY
}

\author{
Satyendra Kumar Mishra, ${ }^{1}$ Surendra Marasini, ${ }^{2}$ Badri Kumar Gupta, ${ }^{3}$ Krishna Kumar Agrawal, ${ }^{4}$ Narayan Gautam
}

\begin{abstract}
\section{INTRODUCTION}

In developing countries like Nepal, iron deficiency anemia (IDA) is one of the major concern. The high rate incidence has been related to insufficient iron intake, accompanied by chronic intestinal blood loss due to parasitic and malarial infections. Therefore, a study was conducted to evaluate the prevalence of IDA in anemic patients of Universal College of Medical Sciences-Teaching Hospital (UCMS-TH), South Western region, Nepal.
\end{abstract}

\section{MATERIAL AND METHODS}

It was a hospital based cross sectional study comprised of 100 anemic patients. Their detailed medical history and lab investigations, focusing on hematological parameters were documented. Peripheral smear examination and serum ferritin estimation were done to observe red cell morphology and iron status respectively.

\section{RESULTS}

This study revealed that out of 100 anemic patients, 35\% were that of IDA. The most affected age group was 21-40 years with frequency $42.55 \%$. IDA was more common in females $(42.85 \%)$ than in male $(21.62 \%)$. Out of 100 anemic patients, microcytic hypochromic anemia was predominant in $47 \%$ followed by macrocytic anemia (31\%) and then normocytic normochromic anemia (22\%). Out of 47 microcytic hypochromic anemic patients, 12 had normal serum ferritin. There was a statistical significant difference in $\mathrm{Hb}(\mathrm{p}=0.011), \mathrm{MCV}(\mathrm{p}=0.0001), \mathrm{MCH}(\mathrm{p}=0.0001), \mathrm{MCHC}(\mathrm{p}=0.0001)$ and serum ferritin $(\mathrm{p}=0.0001)$ among all types of anemia. There was a statistical significant positive correlation of ferritin with Hemoglobin $(0.257, \mathrm{p}=0.01), \operatorname{MCV}(0.772, \mathrm{p}=0.0001), \mathrm{MCH}(0.741, \mathrm{p}=0.0001)$ and $\mathrm{MCHC}(0.494, \mathrm{p}=0.0001)$.

\section{CONCLUSION}

The peripheral smear in conjunction with serum ferritin estimation needs to be included for susceptible individuals to screen the IDA and other types of anemia.

KEYWORDS Anemia, ferritin, iron deficiency anemia, peripheral smear

1. Department of Pathology, Universal College of Medical Sciences, Bhairahawa, Nepal

2. Department of Biochemistry, B.P Koirala Institute of Health Sciences, Dharan, Nepal

3. Department of Pediatrics, Universal College of Medical Sciences, Bhairahawa, Nepal

4. Department of Nephrology, Nepal Medical College, Kathmandu, Nepal

5. Department of Biochemistry, Universal College of Medical Sciences, Bhairahawa, Nepal

DOI: https://doi.org/10.3126/jucms.v6i2.22494

\begin{tabular}{l}
\hline For Correspondence \\
Mr. Narayan Gautam \\
Department of Biochemistry \\
Universal College of Medical Sciences \\
Bhairahawa, Nepal \\
Email: ng_bp22@yahoo.com
\end{tabular}




\section{INTRODUCTION}

Iron deficiency anemia is the commonest type of anemia throughout the world. It is defined as a clinical condition, characterized by reduction in hemoglobin below the normal for the age, sex, physiological conditions and altitude above sea level in a patient. ${ }^{1}$ It is a global problem, mainly affecting poor people, pregnant, lactating females, growing children and elderly people..$^{2-4}$

It has been reported to affect about $50-60 \%$ of young children and pregnant females as well as $20-30 \%$ of non-pregnant females in the developing countries. ${ }^{5-8}$ This high rate has been related to insufficient iron intake, high nutritional needs during childhood and pregnancy, poor bioavailability of iron, and an accompanying chronic intestinal blood loss due to parasitic and malarial infestations. ${ }^{9-13}$ Hence, the study was conducted to evaluate the prevalence of iron deficiency anemia in inhabitants of south western region of Nepal.

\section{MATERIAL AND METHODS}

In this cross sectional study one hundred clinically anemic patients of either sex, with age more than 10 years and hemoglobin less than or equal to $10 \mathrm{gm} / \mathrm{dl}$ were selected from Universal College of Medical Sciences-Teaching Hospital (UCMS-TH), Bhairahawa, Nepal. Detailed history, including history of present illness, past illness, socioeconomic status, dietary habits and alcohol consumption was taken from each patient. In all patients, preliminary blood tests including full blood counts and red cell indices were performed on $5 \mathrm{ml}$ venous blood. Leishman stained blood film was made for every patients and examined.

Further, serum ferritin estimation was performed to confirm the diagnosis. Serum ferritin estimation was done by competitive ELISA method. Serum ferritin $<30 \mathrm{ng} / \mathrm{ml}$ was considered diagnostic in males and $<15 \mathrm{ng} / \mathrm{ml}$ was considered diagnostic in females. Those patients not giving consent to the study and those receiving treatment for malignancies and liver diseases were excluded from the study.

Data were entered in excel worksheet and analyzed in SPSS 20, IBM, Inc., Chicago, IL software. Mean and frequencies of continuous variables were calculated. The analysis of variance (ANOVA) and Pearson's correlation was applied to assess significance differences. A p-value $<0.05$ was considered statistically significant.

\section{RESULTS}

As it was a cross sectional study, one hundred consecutive samples diagnosed as anemia based on hematological parameters, peripheral smear and serum ferritin were enrolled.

Table 1. Distribution of IDA based on demographic features in study subjects $(n=100)$

\begin{tabular}{|c|c|c|c|}
\hline Features & Total anemic patients & Patients with IDA & Frequency of IDA (\%) \\
\hline Terai & 55 & 19 & 34.54 \\
\hline Hill & 45 & 16 & 35.55 \\
\hline Vegetarians & 41 & 17 & 41.46 \\
\hline Non Vegetarians & 59 & 18 & 30.50 \\
\hline Alcoholic & 20 & 8 & 40 \\
\hline Non alcoholic & 80 & 27 & 33.75 \\
\hline Exercise & 35 & 11 & 31.42 \\
\hline Non exercise & 65 & 24 & 36.92 \\
\hline
\end{tabular}

The prevalence of IDA was slightly more in hilly region (35.55\%) (Table 1 ) as compared to terai region (34.54\%). IDA was predominant in vegetarians $(41.46 \%)$ than non vegetarians $(30.50 \%)$. The frequency of IDA was more in alcoholic patients (40\%) as compared to that of non-alcoholic patients $(33.75 \%)$. IDA was more common in non-exercising subjects $(36.92 \%)$ as compared to exercising subjects $(31.42 \%)$.

Table 2. Age distribution of IDA patients in study subjects $(\mathbf{n}=\mathbf{1 0 0})$

\begin{tabular}{|c|c|c|c|}
\hline Age groups (years) & Total Anemic patients & Patients with IDA & IDA (\%) \\
\hline $0-20$ & 10 & 3 & 30 \\
\hline $21-40$ & 47 & 20 & 42.55 \\
\hline $41-60$ & 27 & 7 & 25.92 \\
\hline $61-80$ & 16 & 5 & 31.25 \\
\hline Total & 100 & 35 & 35 \\
\hline
\end{tabular}

The mostly affected age group (Table 2) in anemic patients was $21-40$ years $(42.55 \%)$ followed by $61-80$ years $(31.25 \%)$.

Table 3. Gender wise distribution of IDA in anemic patients $(n=100)$

\begin{tabular}{|c|c|c|c|c|c|}
\hline Sex & $\begin{array}{c}\text { Total anemic } \\
\text { patients }\end{array}$ & $\begin{array}{c}\text { Patient } \\
\text { with IDA }\end{array}$ & $\begin{array}{c}\text { Frequency of } \\
\text { IDA }\end{array}$ & $\begin{array}{c}\text { Patients with other } \\
\text { types of anemia }\end{array}$ & $\begin{array}{c}\text { Other types of } \\
\text { anemia(\%) }\end{array}$ \\
\hline Male & 37 & 8 & $21.62 \%$ & 29 & 78.37 \\
\hline Female & 63 & 27 & $42.85 \%$ & 36 & 57.14 \\
\hline Total & 100 & 35 & $35 \%$ & 65 & 65 \\
\hline
\end{tabular}

The IDA was more common in females (42.85\%) (Table 3) than in male patients $(21.62 \%)$ whereas other types of anemia were observed to be more in males $(78.37 \%)$ than in females $(57.14 \%)$. 


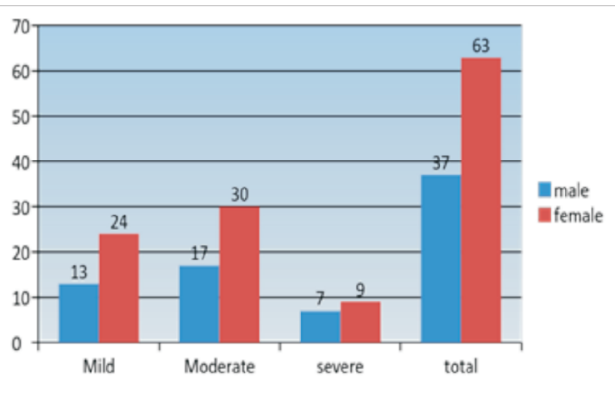

Figure 1. Distribution of anemia [mild anemia $(\mathrm{Hb}=9.1$ $10.5 \mathrm{~g} / \mathrm{dl})$, moderate anemia $(\mathrm{Hb}=6-9 \mathrm{~g} / \mathrm{dl})$ and severe anemia $(\mathrm{Hb}<6.0 \mathrm{~g} / \mathrm{dl})]$ based on hemoglobin level (WHO criteria) $(\mathbf{n}=\mathbf{1 0 0})$

Figure 1 shows that moderate anemia was predominant in $17 \%$ of male and $30 \%$ of female followed by mild anemia, $13 \%$ in male and $24 \%$ in female and severe anemia $7 \%$ in male and $9 \%$ in female. Thus, mild moderate and severe anemia was predominant in female patients than in male patients.

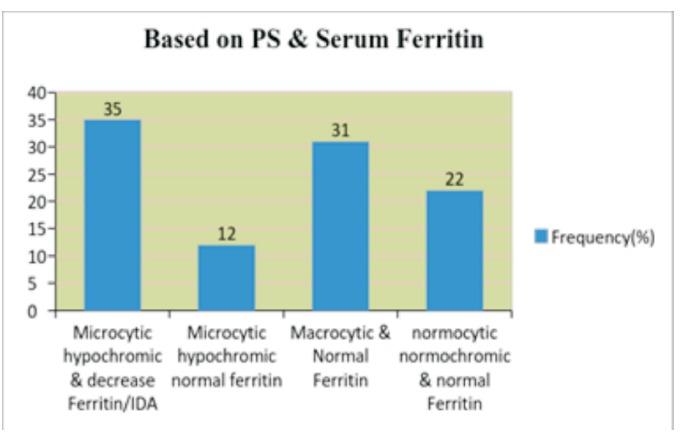

Figure 2. Distribution of patients based on peripheral smear (PS) and serum ferritin

Figure 2 shows that patients with IDA 35\% have microcytic hypochromic anemia and decrease ferritin. 31\%. Patients with macrocytic anemia have normal ferritin and $22 \%$ of patients with normocytic normochromic anemia have normal ferritin. Out of 47 microcytic hypochromic patients, $12 \%$ had normal serum ferritin.

Table 4. Distribution of serum ferritin in anemic patients $(\mathrm{n}=\mathbf{1 0 0})$

\begin{tabular}{|c|c|c|c|}
\hline Ferritin (ng/ml) & Male (\%) & Ferritin (ng/ml) & Female (\%) \\
\hline$<30$ & $8(21.62 \%)$ & $<15$ & $27(42.85 \%)$ \\
\hline $30-300$ & $29(78.38 \%)$ & $15-200$ & $36(57.15 \%)$ \\
\hline Total & 37 & Total & 63 \\
\hline
\end{tabular}

The decrease in serum ferritin in anemic patients was $42.85 \%$ (Table 4 ) in female as compared to $21.62 \%$ in male patients.
Table 5. Hematological parameters in types of anemia $(\mathrm{n}=\mathbf{1 0 0})$

\begin{tabular}{|c|c|c|c|c|}
\hline Variables & Anemia & $\mathbf{N}$ & Mean \pm SD & p-value \\
\hline \multirow{4}{*}{$\begin{array}{l}\mathrm{Hb} \\
(\mathrm{gm} / \mathrm{dl})\end{array}$} & IDA & 35 & $7.43 \pm 1.94$ & \multirow{4}{*}{0.011} \\
\hline & MIHC & 12 & $8.38 \pm 1.23$ & \\
\hline & MAC & 30 & $7.91 \pm 1.77$ & \\
\hline & $\mathrm{NNC}$ & 23 & $8.94 \pm 1.29$ & \\
\hline \multirow{4}{*}{$\begin{array}{l}\text { RBC } \\
(\text { million } / \mu \mathrm{l})\end{array}$} & IDA & 35 & $3.49 \pm .99$ & \multirow{4}{*}{0.082} \\
\hline & MIHC & 12 & $3.87 \pm .87$ & \\
\hline & MAC & 30 & $3.22 \pm .81$ & \\
\hline & $\mathrm{NNC}$ & 23 & $3.17 \pm .64$ & \\
\hline \multirow{4}{*}{$\begin{array}{r}\text { PCV } \\
(\%)\end{array}$} & IDA & 35 & $26.28 \pm 8.17$ & \multirow{4}{*}{0.487} \\
\hline & MIHC & 12 & $27.90 \pm 4.45$ & \\
\hline & MAC & 30 & $27.99 \pm 5.85$ & \\
\hline & $\mathrm{NNC}$ & 23 & $28.77 \pm 3.83$ & \\
\hline \multirow{4}{*}{$\begin{array}{l}\text { MCV } \\
\text { (FL) }\end{array}$} & IDA & 35 & $67.76 \pm 8.62$ & \multirow{4}{*}{0.0001} \\
\hline & MIHC & 12 & $69.91 \pm 8.05$ & \\
\hline & MAC & 30 & $105.30 \pm 5.4$ & \\
\hline & $\mathrm{NNC}$ & 23 & $87.73 \pm 4.56$ & \\
\hline \multirow{4}{*}{$\begin{array}{l}\mathrm{MCH} \\
(\mathrm{pg} / \mathrm{dl})\end{array}$} & IDA & 35 & $21.62 \pm 4.13$ & \multirow{4}{*}{0.0001} \\
\hline & MIHC & 12 & $21.78 \pm 3.52$ & \\
\hline & MAC & 30 & $33.83 \pm 2.29$ & \\
\hline & $\mathrm{NNC}$ & 23 & $29.44 \pm 2.39$ & \\
\hline \multirow{4}{*}{$\begin{array}{l}\text { MCHC } \\
(\mathrm{g} / \mathrm{dl})\end{array}$} & IDA & 35 & $30.28 \pm 1.74$ & \multirow{4}{*}{0.0001} \\
\hline & MIHC & 12 & $30.88 \pm 1.64$ & \\
\hline & MAC & 30 & $32.73 \pm 1.27$ & \\
\hline & $\mathrm{NNC}$ & 23 & $31.83 \pm 1.22$ & \\
\hline \multirow{4}{*}{ Ferritin $(\mathrm{ng} / \mathrm{ml})$} & IDA & 35 & $13.76 \pm 6.53$ & \multirow{4}{*}{0.0001} \\
\hline & MIHC & 12 & $55.74 \pm 40.77$ & \\
\hline & MAC & 30 & $134.84 \pm 21.69$ & \\
\hline & $\mathrm{NNC}$ & 23 & $138.75 \pm 23.45$ & \\
\hline
\end{tabular}

There was a significant difference among types of anemia (Table 5) viz a viz IDA (Microcytic hypochromic and decreased ferritin), MIHC (Microcytic hypochromic and normal ferritin), MAC (Macrocytic and normal ferritin) and NNC (Normocytic normochromic and normal ferritin) with $\mathrm{Hb}(\mathrm{p}=0.011), \mathrm{MCV}(\mathrm{p}=0.0001), \mathrm{MCH}(\mathrm{p}=0.0001), \mathrm{MCHC}$ $(\mathrm{p}=0.0001)$ and serum ferritin $(\mathrm{p}=0.0001)$ respectively.

Table 6. Pearson's correlation of variables in study subjects $(\mathrm{n}=100)$

\begin{tabular}{|l|c|c|}
\hline Variables & Ferritin (r) & p-value \\
\hline Age & 0.170 & 0.09 \\
\hline $\mathrm{Hb}$ & 0.257 & 0.01 \\
\hline $\mathrm{RBCs}$ & -0.166 & 0.098 \\
\hline $\mathrm{MCV}$ & 0.772 & 0.0001 \\
\hline $\mathrm{MCH}$ & 0.741 & 0.0001 \\
\hline $\mathrm{MCHC}$ & 0.494 & 0.0001 \\
\hline $\mathrm{PCV}$ & 0.167 & 0.096 \\
\hline
\end{tabular}

There was a statistical significant positive correlation (Table 6) of ferritin with $\mathrm{Hb}(\mathrm{r}=0.257, \mathrm{p}=0.01), \mathrm{MCV}(\mathrm{r}=0.772, \mathrm{p}=$ $0.0001), \mathrm{MCH}(\mathrm{r}=0.741, \mathrm{p}=0.0001)$ and $\mathrm{MCHC}(\mathrm{r}=0.494$, $\mathrm{p}=0.0001)$. 


\section{DISCUSSION}

The method used for serum ferritin estimation is non-invasive method used to assess the storage of iron in the body. Based on serum ferritin concentrations, most of the patients were found to suffer from IDA (53\%). Females were affected more than males and most affected age group was between $21-30$ years. ${ }^{14}$ Ozdemir N et al have shown that iron level and TIBC fluctuate with age and dietary status of the patients. ${ }^{15}$ Hence, we justify the investigation to be made for peripheral smear and serum ferritin estimation in anemic patients and correlation were made on those parameters to find out IDA.

In our study, the overall prevalence of iron deficiency anemia in anemic patients was $35 \%$, which was more than that of study conducted by Sinha AK et $\mathrm{al}^{16}$ in Biratnagar, Nepal. Their study revealed that $25.57 \%$ patients were suffering from IDA but Lamsal KS et al (TUTH Kathmandu) ${ }^{17}$ showed that $41.35 \%$ patients were having IDA which was more than that of our study. The reason may include increased demand of iron by body in pregnancy, increased loss of iron due to parasitic infestation or due to chronic blood loss, low iron intake, and may be due to decreased absorption of iron.

Our study revealed that the majority of the patients with IDA were in age between $21-40$ years $(42.55 \%)$ followed by age group between 61-80 years (31.55\%). This is similar to that of study conducted by Sinha AK et al ${ }^{16}$ and Patel $\mathrm{S}$ et al ${ }^{14}$. The age group 21-40 includes the females of reproductive age group, increased demand of iron during pregnancy; menstrual blood loss and excessive bleeding during labor period might be the possible reasons. $^{18-20}$

In our study, we also have shown distribution of the IDA with dietary habits of patients. The prevalence of IDA was more in vegetarian patients $(41.46 \%)$ followed by non vegetarian patients $(30.50 \%)$. This is because the iron-rich foods such as beans present low bio availability due to the presence of phytates and fibers. On the other hand, meats have much more iron contents with high bio availability and absorption. Heme iron in meat is easily absorbed from mucosa of duodenum in comparison to non heme iron in vegetables. ${ }^{21-23}$

The current study revealed that the prevalence of IDA was more in anemic patients of hilly region $(35.55 \%)$ followed by terai region $(34.54 \%)$. This may be due to low socioeconomic status, decreased supply of iron pills in pregnant women of rural areas of hilly region, increased parasitic infestations and lack of de-worming in the patients of hilly region. ${ }^{24}$

In our study, the prevalence of IDA was more in alcoholic patients $(40 \%)$ as compared to that of non-alcoholic patients
(33.75\%). From the study of Harold S Ballard, ${ }^{25}$ alcohol consumption interferes the proper absorption of iron into the hemoglobin molecules of red blood cells (RBCs). In many alcoholic patients, blood loss and subsequent iron deficiency are caused by gastrointestinal bleeding. Iron deficiency in alcoholics often is difficult to diagnose because it may be masked by symptoms of other nutritional deficiencies (e.g., folic acid deficiency) or by coexisting liver disease and other alcohol-related inflammatory conditions. ${ }^{25}$

The categorization of anemic patients based on the peripheral smear examination revealed that there was predominance of microcytic hypochromic anemia (47\%) followed by macrocytic anemia (31\%) then normocytic normochromic anemia $(22 \%)$. Out of 47 microcytic hypochromic anemic patients, 35 patients were having IDA which was confirmed by measuring serum ferritin level of the patients, the remaining 12 patients having microcytic hypochromic blood picture had normal serum ferritin. Serum ferritin was also performed in macrocytic and normocytic normochromic individuals and results were found within normal range. This was similar result as that of $\mathrm{WHO} / \mathrm{CDC}$ which had shown that IDA was one of the major concerns in health in developing countries like Nepal. ${ }^{8,12}$ However, large number of samples with multi centric approach is required to validate the limitation behind present study.

\section{CONCLUSION}

This study recommends that no anemic patients should be treated blindly just seeing the hemoglobin level. They must be investigated to find out the cause and type of anemia before starting the treatment. The peripheral smear in conjunction with serum ferritin estimation needs to be included for susceptible individuals to screen the IDA and other types of anemia.

\section{ACKNOWLEDGEMENTS}

All participants of the study and laboratory staffs of UCMS$\mathrm{TH}$ who have directly or indirectly involved in sample processing. 


\section{REFERENCES}

1. Viteri Fe. A new concept in the control of iron deficiency: Community based preventive supplementation of at risk groups by weekly intake of iron supplements. Biomed Environ Sci 1998; 11(1): 46-60.

2. Cook JD. Iron deficiency anemia. Baillieres Clinical Hematology 1994; 7: 787-804

3. Wintrobe's clinical hematology Etiological factors in iron deficiency. Philadelphia: Lea and Febiger; $1993.9^{\text {th }}$ edition

4. Weissinger F. Basic Principals and clinical significance of iron deficiency. Fortsch Med 1999; 115(31): 35-38.

5. Iron deficiency. Bulletin of the World Health Organization, 1998; 76: 121-123.

6. WHO. Preventing and controlling iron deficiency anemia through primary health care .Geneva. 1989: 1-36.

7. Bothwell $\mathrm{TH}$, Charlton RW, Cook JD, Finch CA. Iron metabolism in man .Oxford: Blackwell Scientific Publications, 1979: 44-811.

8. Centers for disease control (CDC). MMWR Weekly: Iron deficiency United States, 1999-2000. 2002.

9. Wu AC, Lesperance L. and Bernstein H. Screening for iron deficiency. Pediatric Review 2002 ; 23(5): 171-177.

10. Tender J and Cheng T. L. Iron deficiency anemia. In: F D Burg R Ingelfinger RA Polin and A Gershon (Eds). Gellis and Kagan's current pediatrics therapy 2002: 633-637.

11. Ioli J.G. Anemia. In J.A. Fox (Ed).Primary health care of infants, children and adolescents (2ndEd).2002: 471-480.

12. Recommendations to prevent and control iron deficiency in the United States. Centers for Disease Control and Prevention. MMWR Recommend Rep. 1998; 3(47): 1-29.

13. Beutler E, Lichtman MA, Collar B. S. Williams's hematology 6th Ed. New York: McGraw-Hill; 2000.

14. Patel S, Shah M, Patel J and Kumar N. Iron deficiency anaemia in moderate to severely anaemic patients, Gujarat Medical Journal 2009; 64 (2): 15-17.

15. Ozdemir N. Iron deficiency anemia from diagnosis to treatment in children. Türk Ped Arş 2015; 50: 11-9.

16. Sinha AN and Majumdar B. Incidence of anemia based on haemoglobin levels in children 2-12 years of aged in Nobe Medical College Teaching Hospital, Biratnagar, Nepal. Journal of Nobel Medical College 2012; 1(2):36-38.

17. KS Lamsal. Clinical profile of patients with anemia. Journal of Institute of Medicine, December, 2009;31(3): 30-33
18. Jennifer H and Haas JD. Hemoglobin correction factors for estimating the prevalence of iron deficiency anemia in pregnant women residing at high altitudes in Bolivia. Rev Panam Salud Publica/Pan Am J Public Health, 1999.

19. Park K. Textbook of Preventive and Social Medicine, $22^{\text {nd }}$ edition. Banarasidas Bhanot Publishers Jabalpur, 2013; 840 .

20. Child and maternal nutrition. Situation of children and women in Nepal Kathmandu, Nepal: UN Nepal Information Platform. The United Nations Children's Fund (UNICEF), 2006: 121-126.

21. Layrisse M, Martinez-Torres C, Roche M. The effects of interaction of various foods on iron absorption. Am J Clinical Nutr 1968; 11:1175-83

22. Souza Queiroz S. Anemia: aspects pathophysiology experiences com autilização do leite fortification com ferro. Ped Mod 1995; 31: 441-55.

23. Pavord S, Myers B, Robinson S, Allard S, Strong G, Oppenheimer C. UK guidelines on the management of iron deficiency in pregnancy. British Journal of Haematology. 2012; 156(5): 588-600.

24. Baral KP and Onta SR. Prevalence of anemia amongst adolescents in Nepal: a community based study in rural and urban areas of Morang District Nepal Med Coll J 2009; 11(3): 179-182.Ballard, H.S. Hematological complications of alcoholism. Alcoholism: Clinical and Experimental Research 1989; $13(5): 706-720$ 